\title{
PENYAKIT KARAT TUMOR PADA SENGON (Paraserianthes falcataria (L) Nielsen) DI PERKEBUNAN GLENMORE BANYUWANGI, JAWA TIMUR
}

\author{
Gall Rust Disease on Sengon (Paraserianthes falcataria (L) Nielsen) in Glenmore Plantation, \\ Banyuwangi, East Java \\ Illa Anggraeni \\ Pusat Litbang Hutan Tanaman \\ Kampus Balitbang Kehutanan \\ Jl. Gunung Batu No. 5, Po BOX 133, Bogor 16610 \\ Telp. (0251) 8631238, Fax. (0251) 7520005
}

Naskah masuk : 8 Juli 2008; Naskah diterima : 3 April 2009

\begin{abstract}
Sengon (Paraserianthes falcataria (L) Nielsen) is one of the species that has been planted in forest plantation area, community forest and estate area in Java and outside Java for a long time. Current issue in the development of sengon plantation is the attack of gall rust disease caused by Uromycladium tepperianum. The objective of this study was to identify the characteristic of the disease, percentage of occurrence, intensity of the disease, and the preliminary control. For controlling the disease, some synthetic fungicides with active ingredients were used namely: difenokonazol of $250 \mathrm{~g} / \mathrm{l}$, hydroxide crumn of $82,4 \mathrm{~g} / \mathrm{l}$, metil tiofanat of $500 \mathrm{~g} / \mathrm{l}$, propineb of $70 \%$, and klorotalonil of $75 \%$. Some materials were also used namely liquid of spiritus, lime and salt with ratio of $10: 1$ and mixture of sulphure and lime with ratio of $1: 1$. Study was carried out in Glenmore estate area, Banyuwangi. The result showed that synthetic fungicide were not effective while application of the mixture of sulphur and lime could prevent and control the gall.
\end{abstract}

Key words: Gall rust disease, Paraserianthes falcataria, Uromycladium tepperianum

\begin{abstract}
ABSTRAK
Sengon (Paraserianthes falcataria (L) Nielsen), salah satu jenis tanaman yang sudah sejak lama diusahakan di kawasan hutan tanaman, hutan rakyat dan perkebunan di Pulau Jawa maupun di luar Pulau Jawa. Saat ini masalah utama yang dihadapi dalam pengembangan sengon adalah adanya serangan penyakit karat tumor yang disebabkan oleh fungi Uromycladium tepperianum. Sehubungan dengan hal tersebut di atas maka tujuan dari penelitian ini adalah untuk mengetahui karakteristik penyakit, gejala penyakit, persentase kejadian penyakit (disease incidence), intensitas penyakit (diseases severity), dan uji pengendalian pendahuluan menggunakan berbagai fungisida sintetik yang berbahan aktif difenokonazol $250 \mathrm{~g} / \mathrm{l}$, tembaga hidroksida $82,4 \mathrm{~g} / \mathrm{l}$, metil tiofanat $500 \mathrm{~g} / \mathrm{l}$, propineb $70 \%$, klorotalonil $75 \%$. Selain fungisida sintetik juga digunakan beberapa bahan yang mudah di dapat oleh pengelola yaitu larutan spirtus, kapur campur garam dengan perbandingan 10:1 dan belerang campur kapur dengan perbandingan $1: 1$. Penelitian dilaksanakan di areal perkebunan PT. Glenmore, Banyuwangi Jawa Timur. Hasil penelitian menunjukkan bahwa aplikasi perlakuan fungisida sintetik tidak efektif sedangkan penggunaan campuran belerang dan kapur dapat mencegah dan mengendalikan karat tumor.
\end{abstract}

\section{Kata kunci : karat tumor, Sengon, Uromycladium tepperianum}

\section{PENDAHULUAN}

Sengon (Paraserianthes falcataria (L) Nielsen) termasuk dalam famili Mimosaceae, pernah dijuluki sebagai pohon ajaib (miracle tree) karena dapat tumbuh dengan cepat dan dapat beradaptasi pada berbagai keadaan lingkungan. Tanaman sengon bersifat multifungsi dan memberikan dampak ganda, baik 
sebagai tanaman produksi maupun sebagai tanaman konservasi dan reboisasi. Beberapa kegunaan sengon antara lain sebagai pohon pelindung, meningkatkan kesuburan tanah karena bersimbiose dengan bakteri bintil akar, kayunya dimanfaatkan sebagai bahan industri seperti tusuk gigi, korek api, sumpit, peti kemas mebel, pulp dan kertas, kerajinan, kayu lapis, venir, bahan bangunan, dan perabot rumah tangga serta bahan baku kayu bakar; daunnya untuk makanan ternak dan pupuk hijau; biji/buahnya dapat dimakan oleh manusia (Anonimous, 1990).

Saat ini sengon banyak diusahakan di kawasan hutan tanaman, perkebunan maupun di kebunkebun milik rakyat di Pulau Jawa (Garut, Ciamis, Wonosobo, Magelang, Salatiga, Temanggung, Banjarnegara, Banyumas, Pacitan, Magetan, Kediri, Probolinggo, Malang, Jember, Lumajang, dan Banyuwangi) maupun di luar Pulau Jawa (Kalimantan, Sumatera dan Kepulauan Maluku). Khusus di Pulau Jawa tepatnya di Jawa Timur banyak perusahaan dan perkebunan yang mengusahakan tanaman sengon, salah satunya adalah perkebunan swasta PT. Glenmore di Banyuwangi yang telah menanam sengon seluas 30 hektar pada tahun 2004. Tetapi penanaman sengon kurang berhasil karena pada akhir tahun 2004 tanaman tersebut diserang penyakit karat tumor. Masalah penyakit karat tumor tidak hanya terjadi di perkebunan tersebut. Berdasarkan informasi yang diperoleh Pusat Litbang Hutan Tanaman, ledakan serangan penyakit karat tumor juga terjadi di :

1. Kabupaten Lumajang, tepatnya di lokasi pelaksanaan kegiatan GN-RHL/GERHAN tahun tanam 2003 seluas 300 ha, 2004 seluas 1.350 ha dan 2005 seluas 775 ha (Surat Kepala Dinas Kehutanan Kabupaten Lumajang No. 522/211/427.50/2006 dan No. 522/345/427.50/2006).

2. Kabupaten Probolinggo (Kecamatan Krucil), Kabupaten Banyuwangi (Kecamatan Kalibaru) dan Kabupaten Lumajang; Tanaman sengon milik masyarakat, perkebunan dan instansi lainnya sebagai mitra/non mitra perusahaan plywood and wood industry PT. Kutai Timber Indonesia (Surat Direktur PT. Kutai Timber Indonesia No. 469/IX/KTIP/A-16/2006).

3. Beberapa kebun dalam lingkungan PT. Perkebunan Nusantara XII (Persero) yaitu UUS Kertowono (Kabupaten Lumajang), UUS Gunung Gumitir (Kabupaten Banyuwangi), UUS Jatirono dan UUS Malangsari (Kabupaten Banyuwangi) (Surat Kepala PT. Perkebunan Nusantara XII (Persero) No. 22/X/071/I/2007)

4. Kabupaten Pacitan, pada tanaman sengon milik rakyat (Surat Kepala Dinas Kehutanan dan Perkebunan Kabupaten Pacitan No. 522.21/388/408.32/2008 tanggal 15 April 2008).

5. Areal Perum Perhutani KPH Kediri, BKPH Pare, RPH Pandantoyo, pada tanaman sengon dengan berbagai umur tanam (Surat Kepala Balai Besar Penelitian Bioteknologi dan Pemuliaan Tanaman Hutan, Yogyakarta No. ND 268/VIII/BBPBTH-1/2008 tanggal 25 April 2008).

Serangan penyakit karat tumor pada sengon juga pernah terjadi pada tahun 1996 di Maluku (Surat Kepala Kantor Wilayah Kehutanan Provinsi Maluku). Pada Januari 1997 tim peneliti Perlindungan Hutan telah melakukan pengamatan di kawasan hutan tanaman industri PT. Artika Optima Inti (Jayanti Group) yang terletak di Pulau Seram, dan menemukan serangan penyakit dengan persentase $100 \%$ pada bibit yang mengakibatkan kematian bibit (fuso), sedangkan pada tegakan umur 3 tahun persentase serangan sebesar 21,47\% dan tegakan 5 tahun sebesar 100\% (Anggraeni dan Santoso, 2003). Old ( 2002) melaporkan bahwa penyakit karat tumor juga menyerang sengon sebagai pohon perindang perkebunan kopi di Timor Lorosae dengan persentase serangan 57\% - 90\%. Penyakit karat tumor menyerang mulai dari bibit, tanaman muda dan tegakan di lapangan yang mengakibatkan pertumbuhan tanaman terhambat, bahkan mematikan tanaman sehingga terjadi kegagalan penanaman. Hal ini merupakan suatu masalah yang perlu mendapat perhatian yang sangat serius, karena menimbulkan kerugian secara ekonomi. Sehubungan dengan hal tersebut maka tujuan dari penelitian ini adalah untuk mengetahui persentase kejadian penyakit (disease incidence) dan intensitas penyakit (diseases intensity) karat tumor serta uji pengendalian pendahuluan di perkebunan PT. Glenmore Banyuwangi, Jawa Timur.

\section{BAHAN DAN METODE}

\section{A. Lokasi Penelitian}

Kegiatan penelitian lapangan dilaksanakan pada tahun 2007 di areal perkebunan PT. Glenmore Banyuwangi, Jawa Timur. Lokasi terletak pada ketinggian 400 - $550 \mathrm{~m}$ dari permukaan laut, dengan tipe 
tanah Alluvial dan iklim tipe B (Schmidt dan Ferguson, 1951). Luas areal tanaman sengon seluruhnya 30 hektar dengan umur tanaman sengon 3 tahun (tahun tanam 2004) dan jarak tanam 2,5 x 2,5 m dan $3 \times 3 \mathrm{~m}$. Penelitian kemudian dilanjutkan di Laboratorium Penyakit, Kelompok Peneliti Perlindungan Hutan, Puslitbang Hutan Tanaman, Bogor.

\section{B. Bahan dan Alat}

Bahan-bahan yang digunakan dalam penelitian ini antara lain alkohol, xylol, parafin, safranin, Canada balsem, gliserin albumin, kertas koran, akuades steril, fungisida berbahan aktif difenokonazol $250 \mathrm{~g} / 1$, tembaga hidroksida $82,4 \mathrm{~g} / 1$, metil tiofanat $500 \mathrm{~g} / \mathrm{l}$, propineb $70 \%$, klorotalonil $75 \%$, kapur, belerang, garam dapur, cat dan pengencer cat. Alat-alat yang digunakan antara lain loupe, pisau, pinset, tali plastik, kantong plastik, lampu spiritus, obyek gelas-gelas penutup, mikrotom, kuas, ember, bor, infus (tempat film), foto-mikroskop dan kamera.

\section{Metode Penelitian}

Penelitian dilakukan dengan menggunakan dua tahapan pekerjaan, yaitu observasi/ pengamatan di lapangan dan di laboratorium.

\section{Pengamatan di Lapangan :}

Pembuatan plot pengamatan sebanyak 5 plot, masing-masing plot terdiri dari 100 pohon. Pada setiap plot dilakukan pengamatan gejala penyakit, persentase kejadian penyakit dan intensitas penyakit. Selain melakukan pengamatan juga melakukan pengambilan material tanaman yang terserang penyakit. Persentase kejadian penyakit pada setiap plot pengamatan, dihitung dengan rumus :

$$
\mathrm{P}=\frac{\mathrm{n}}{\mathrm{N}} \mathrm{X} 100 \%
$$

$\mathrm{P}=$ kejadian penyakit

$\mathrm{N}=$ jumlah pohon yang terserang penyakit dalam plot pengamtan

$\mathrm{N}=$ jumlah seluruh pohon dalam plot pengamatan

Intensitas serangandenyakit pada setiap plot pengamatan, dihitung dengan rumus :

$$
\mathrm{P}=\frac{\mathrm{N}_{1}}{\mathrm{NV}} \mathrm{X} 100 \%
$$

$\mathrm{IP}=$ intensitas serangan penyakit

$\mathrm{N}_{\mathrm{i}}=$ jumlah pohon dengan skor ke $\mathrm{i}$

$\mathrm{V}_{\mathrm{i}}=$ nilai skor penyakit dari $0,1,2,3$ dan 4

$\mathrm{N}=$ jumlah pohon yang diamati

$\mathrm{V}=$ skor tertinggi

Intensitas serangan penyakit didasarkan atas kriteria serangan karat tumor terdapat pada Tabel 1. 
Tabel (Table) 1. Intensitas serangan penyakit (Disease intensity)

\begin{tabular}{|c|l|}
\hline Nilai Skor (Score) & Deskripsi serangan (Description) \\
\hline 0 & tidak terserang penyakit (sehat) \\
1 & serangan ringan $(0<\mathrm{x} \leq 25 \%)$ \\
2 & serangan sedang $(25 \%<\mathrm{x} \leq 50 \%)$ \\
3 & serangan berat $(50 \%<\mathrm{x} \leq 75 \%)$ \\
4 & serangan sangat berat sampai mati $(75 \%<\mathrm{x} \leq 100 \%)$ \\
\hline
\end{tabular}

Uji coba pengendalian di lapangan pada tanaman sengon yang terserang penyakit karat tumor dilakukan dengan menggunakan fungisida kimia sintetik dengan bahan aktif difenokonazol $250 \mathrm{~g} / \mathrm{l}$, tembaga hidroksida $82,4 \mathrm{~g} / \mathrm{l}$, metil tiofanat $500 \mathrm{~g} / \mathrm{l}$, propineb $70 \%$, klorotalonil $75 \%$ dengan dosis 10 cc/pohon. Aplikasi perlakuan dilakukan dengan cara bor-infus, sebagai berikut : batang sengon dilubangi sedalam $\pm 5 \mathrm{~cm}$ menggunakan bor yang arahnya miring ke bawah dengan ketinggian $\pm 100 \mathrm{~cm}$ dari permukaan tanah. Botol infus dibuat dari plastik bekas tempat film yang telah dilubangi bagian bawahnya dan disambung dengan selang plastik (diameter $0,5 \mathrm{~cm}$ ). Botol diisi fungisida sesuai dosis dan digantung diatas lubang bor dengan ujung selang plastik dimasukkan ke dalam lubang bor (Gambar 1).
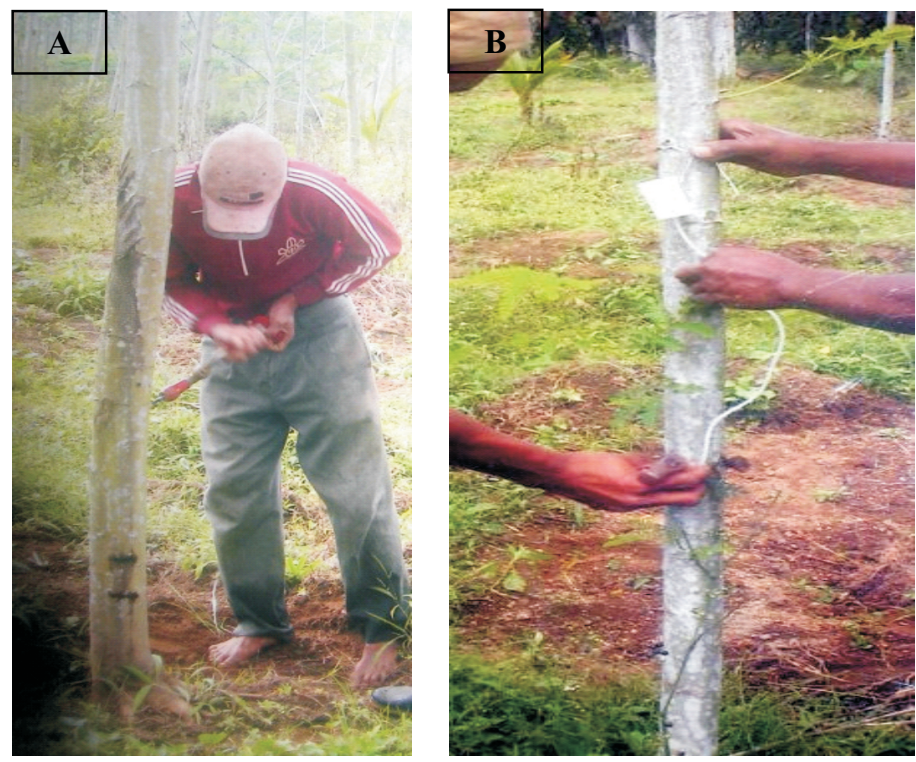

Gambar (Figure) 1. A. Pengeboran batang (Stem boring), B. Pemasangan infus (Infuse installing)

Dengan cara infus ini diharapkan fungisida secara perlahan mengalir dari botol infus ke lubang bor melalui selang plastik ke dalam jaringan batang. Masing-masing fungisida dicoba pada 10 pohon dari tiap plot. Selain menggunakan fungisida kimia sintetik, uji coba pengendalian juga menggunakan larutan spiritus (langsung dilaburkan), kapur campur garam dengan perbandingan 10:1 yang dilarutkan dalam 51 air (untuk labur), 101 air (untuk semprot) dan belerang campur kapur dengan perbandingan 1: 1 yang dilarutkan dalam 51 air (untuk labur), 101 air (untuk semprot).

Aplikasi perlakuan dilakukan dengan cara pohon yang akan diobati terlebih dahulu dihilangkan tumornya hingga bersih dengan cara mengupasnya. Bila tumor tumbuh pada batang dan memotong/ memangkas bila tumor tumbuh pada pucuk daun (Gambar 2), kemudian luka bekas sayatan pada batang dioles bahan-bahan tersebut di atas hingga rata dengan kuas. Setelah dioles kemudian ditutup plastik hitam untuk menghindar terkena air hujan, sedangkan bekas pangkasan pada pucuk disemprot (Gambar 3). Perlakuan dilakukan setiap 1 bulan sekali, dimulai pada bulan April sampai dengan Agustus 2007. Pengamatan timbul dan tidaknya tumor pada tanaman yang telah diberi perlakuan dilakukan 2 bulan sekali. 

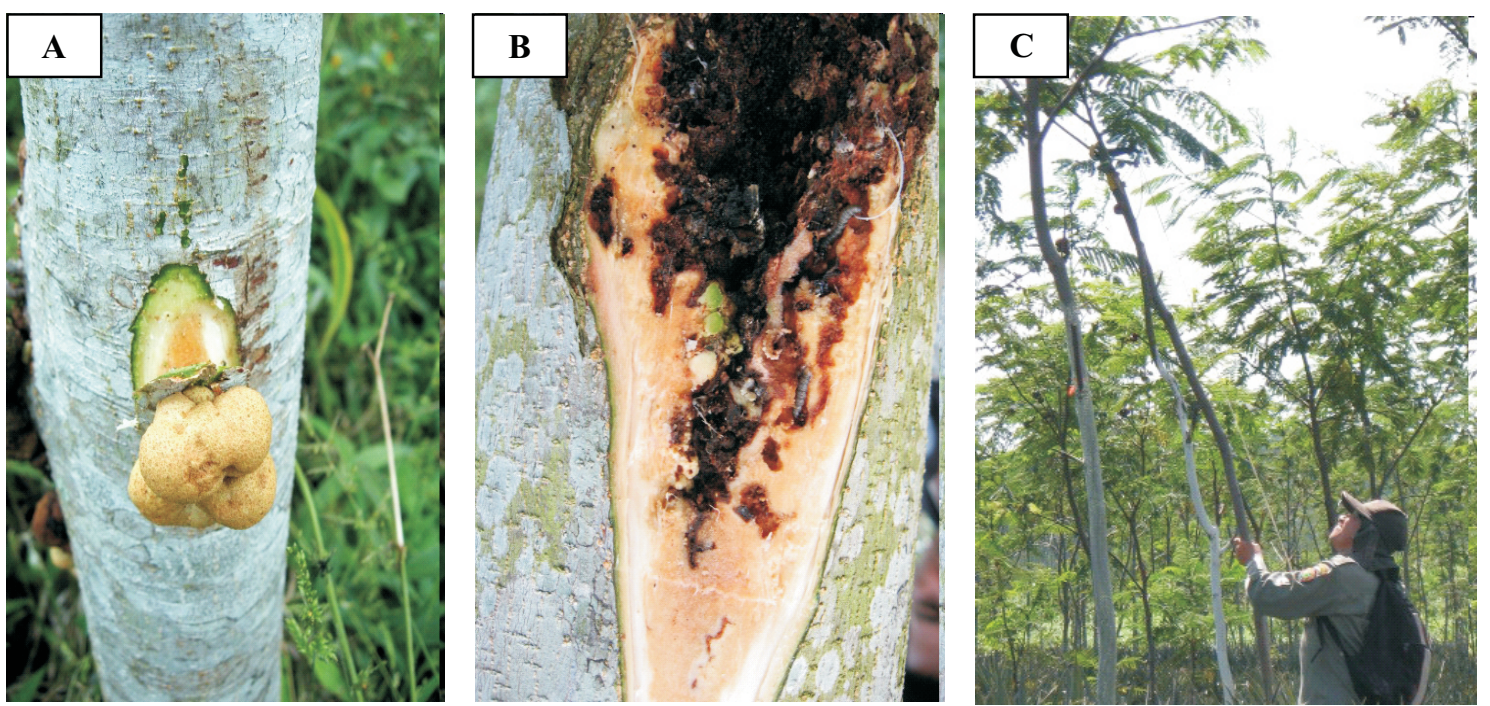

Gambar(Figure)2. A. Pengupasan tumor (Gall peeling), B. Tumor yang sudah dikupas (Peeled gall), C. Pemangkasan tumor (Gall pruning)
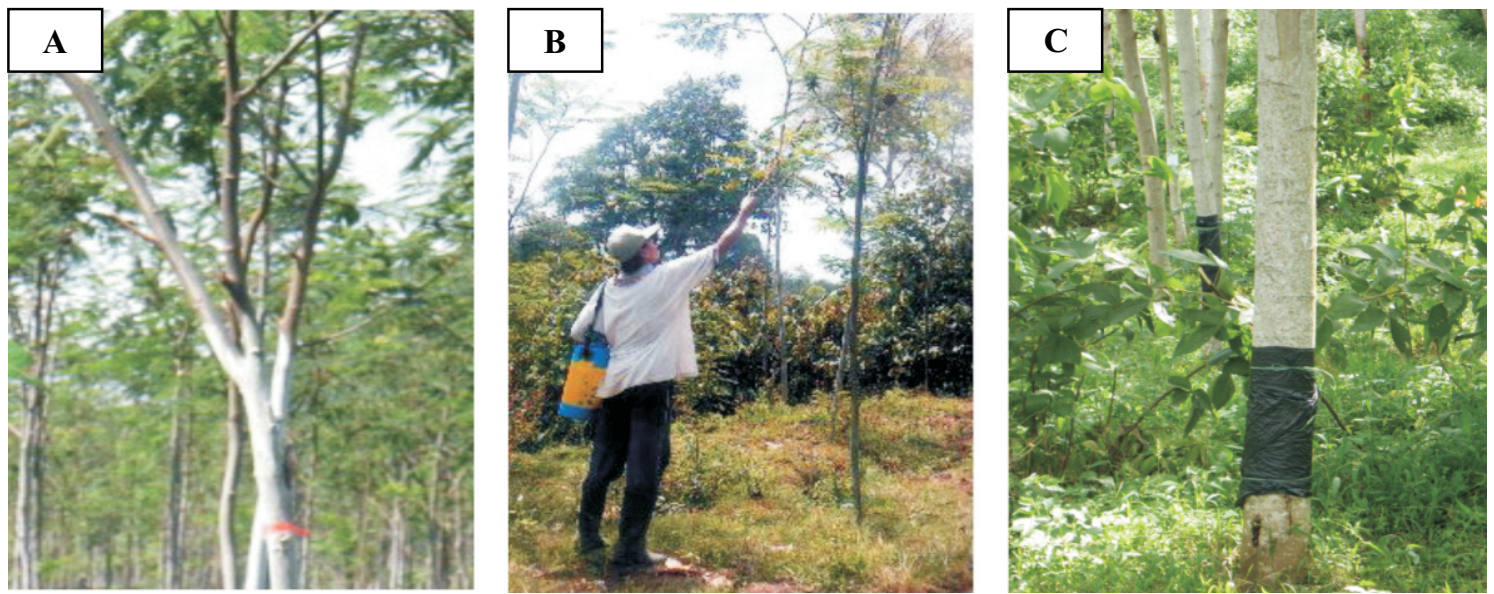

Gambar(Figure) 3. A. Pelaburan dengan kapur (Lime brushing), B. Penyemprotan (Spraying), C. Penutupan dengan plastik hitam untuk mencegah air hujan (Covering by black plastic to prevent the rain)

\section{Pengamatan di Laboratorium :}

Untuk mengetahui bentuk spora dan tubuh buah dari patogen penyebab penyakit karat tumor dilakukan pembuatan preparat permanen. Pembuatan preparat permanen dilakukan melalui tahapantahapan sebagai berikut:

a. Tahap fiksasi, yaitu bagian tanaman yang terserang/sakit dan yang tidak terserang/sehat dipotong potong $( \pm 2-5 \mathrm{~cm})$, dimasukkan dalam larutan FAA yang terdiri dari formalin $(90 \mathrm{ml})+$ asam asetat ( $5 \mathrm{ml})+$ alkohol $70 \%(5 \mathrm{ml})$.

b. Tahap pencucian dan dehidrasi, setelah tahap fiksasi material penyakit dimasukkan ke dalam alkohol secara berurutan mulai dari alkohol 50\% selama 30 menit, alkohol 70\% selama 30 menit, alkohol $95 \%$ selama 30 menit dan terakhir alkohol 100\% selama 30 menit.

c. Tahap dealkoholisasi, material direndam dalam campuran sebagai berikut :

Alkohol 100\% : xylol $=3: 1$ selama 30 menit 
Alkohol 100\%: xylol $=1: 1$ selama 30 menit

Alkohol 100\%: xylol $=1: 3$ selama 30 menit

Xylol I selama 30 menit

Xylol II selama 30 menit pada saat material dalam xylol II dimasukkan parafin (perbandingan xylol : parafin $1: 9$ dalam volume) kemudian dimasukkan dalam oven dengan suhu $57^{\circ} \mathrm{C}$ selama $48 \mathrm{jam}$.

d. Tahap infiltrasi, campuran xylol dan parafin dibuang diganti dengan parafin murni, kemudian dimasukkan kembali dalam oven dengan suhu $57^{\circ} \mathrm{C}$ selama 48 jam.

e. Tahap penyelubungan, parafin dibuang kembali diganti dengan parafin baru, dan dicetak menyerupai balok-balok kecil dimana di dalamnya terdapat material penyakit.

f. Tahap pengirisan, balok parafin dibuat irisan-irisan tipis transparan dengan menggunakan mikrotom $(15 \mu \mathrm{m})$.

g. Tahap perekatan, irisan dilekatkan pada gelas obyek menggunakan gliserin - albumin, kemudian gelas obyek dimasukkan dalam oven dengan suhu $45^{\circ} \mathrm{C}$ selama 48 jam.

h. Tahap pewarnaan, pewarnaan tunggal menggunakan safranin $1 \%$ dengan campuran air. Pewarnaan dilakukan dengan mencelupkan gelas obyek berisi material secara berturutan kedalam xylol I selama 3 menit, xylol II selama 3 menit, alkohol : xylol $(1: 3)$ selama 3 menit, alkohol : xylol $(1: 1)$ selama 3 menit, alkohol : xylol ( $3: 1$ ) selama 3 menit, alkohol 100\% I selama 3 menit, alkohol 100\% II selama 3 menit, alkohol 95\% selama 3 menit, alkohol 70\% selama 3 menit, alkohol 50\% selama 3 menit, safranin 1\% dalam air selama 2 jam, kemudian dimasukkan dalam alkohol 50\% selama 3 menit, alkohol 70\% selama 3 menit, alkohol 95\% selama 3 menit, alkohol 100\% I selama 3 menit, alkohol 100\% II selama 3 menit, alkohol :xylol $3: 1$ selama 3 menit, alkohol : xylol (1:1) selama 3 menit, alkohol : xylol $(1: 3)$ selama 3 menit, xylol I selama 3 menit, xylol II selama 3 menit.

i. Tahap penutupan, irisan pada gelas obyek ditutup dengan gelas penutup yang terlebih dahulu diberi balsem kanada, kemudian preparat dikeringkan pada temperatur $45^{\circ} \mathrm{C}$ atau hingga perekatnya kering. Setelah tahap-tahap tersebut di atas selesai, preparat diamati dan difoto dibawah foto-mikroskop.

\section{HASIL DAN PEMBAHASAN}

\section{A. Pengamatan di Lapangan}

\section{Gejala Penyakit}

Penyakit karat tumor pada sengon menunjukkan gejala yang khas, yaitu hiperplasia (pertumbuhan lebih) pada bagian tumbuhan yang terserang. Gejala penyakit diawali dengan adanya pembengkakan lokal (tumefaksi) di bagian tanaman yang terserang (daun, cabang, dan batang) (Gambar 4). Lama kelamaan pembengkakan berubah menjadi benjolan-benjolan yang kemudian menjadi bintil bintil kecil atau disebut tumor (gall). Tumor yang timbul mempunyai bentuk bervariasi mulai bulat sampai tidak beraturan dengan diameter mulai dari beberapa milimeter sampai lebih besar dari $10 \mathrm{~cm}$. Tumor tersebut dapat berkelompok atau menyebar pada bagian yang terserang (Gambar 5). Tumor yang masih muda berwarna hijau kecoklatan muda yang diselimuti oleh lapisan seperti tepung berwarna agak kemerahan yang merupakan kumpulan dari spora patogen, sedangkan tumor yang tua berwarna coklat kemerahan sampai hitam dan biasanya tumor sudah keropos berlobang serta digunakan sebagai sarang semut. Apabila yang terserang penyakit bagian tangkai daun majemuk atau tajuk maka bagian tersebut agak membengkok karena adanya penebalan dan pembengkakan kemudian tajuk daun menggulung berubah bentuk (malformasi) tanpa daun lagi (Gambar 6). Serangan pada daun diawali dengan bentuk daun agak mengeriting, tangkai daun terbentuk tumor. Jika tanaman mengalami serangan yang parah, maka seluruh bagian tanaman dipenuhi oleh tumor, kemudian daun mengering mengalami kerontokan, diikuti oleh batang dan cabang pohon dan akhirnya tanaman mati. 

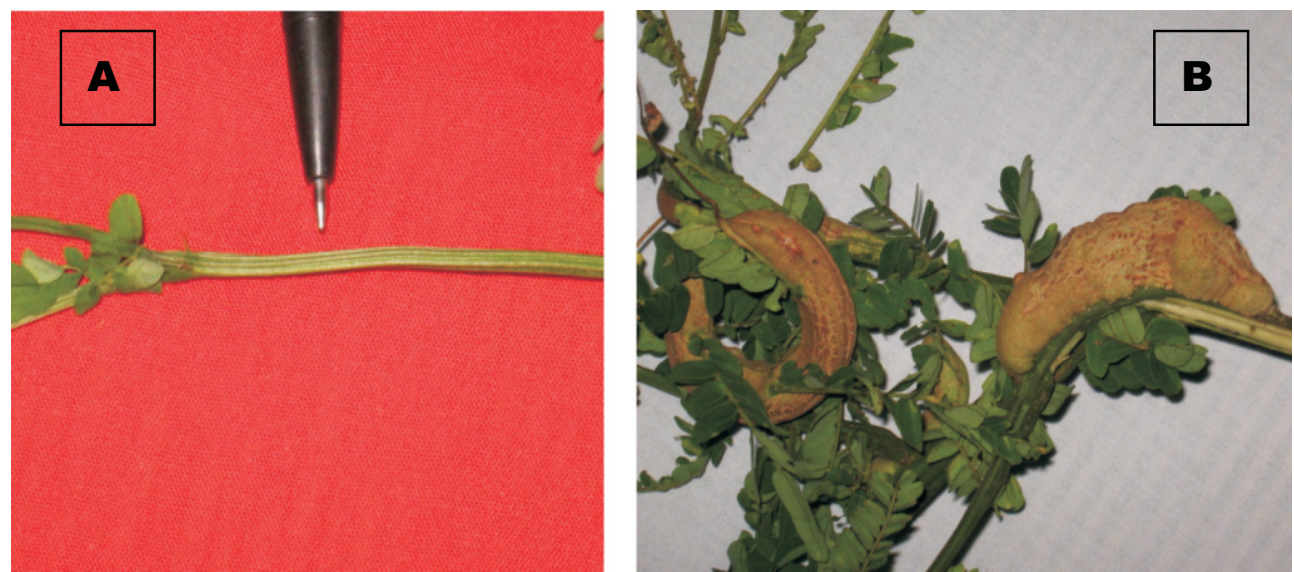

Gambar (Figure) 4. A. Gejala penyakit karat tumor pada bibit (Symptom of gall rust disease on seedling), B. Gejala penyakit karat tumor pada tanaman muda (Symptom of gall rust disease on young trees)

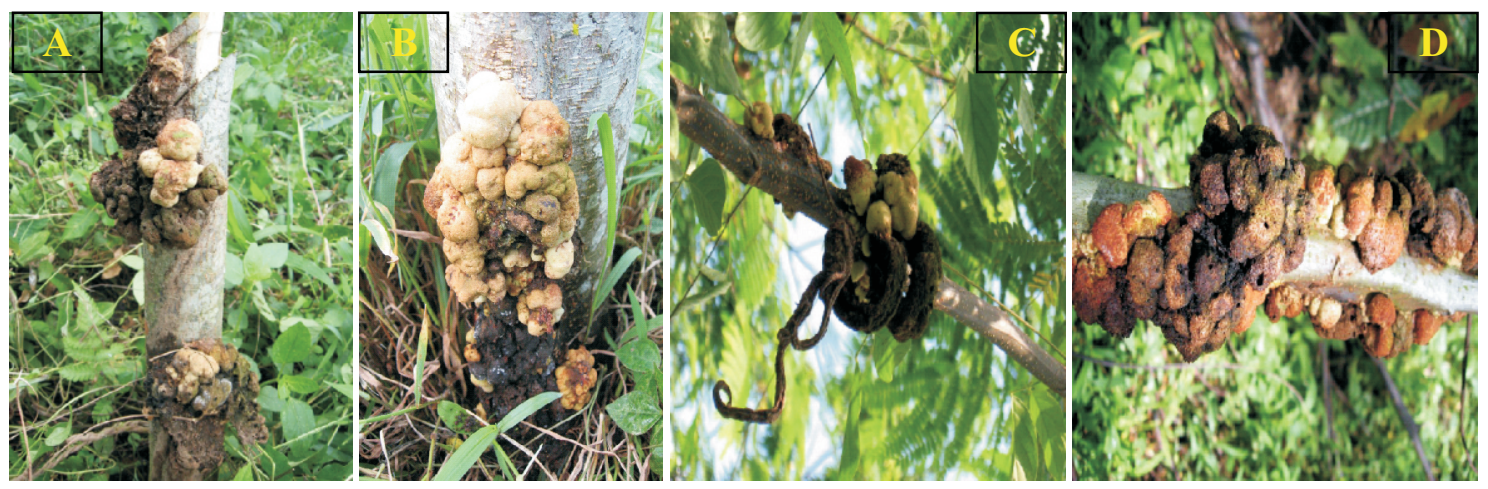

Gambar(Figure) 5. A dan B. Tumor pada batang (Gall on stem), C. Tumor pada pucuk daun (Gall on shoot), D. Tumor pada cabang (Gall on branch)
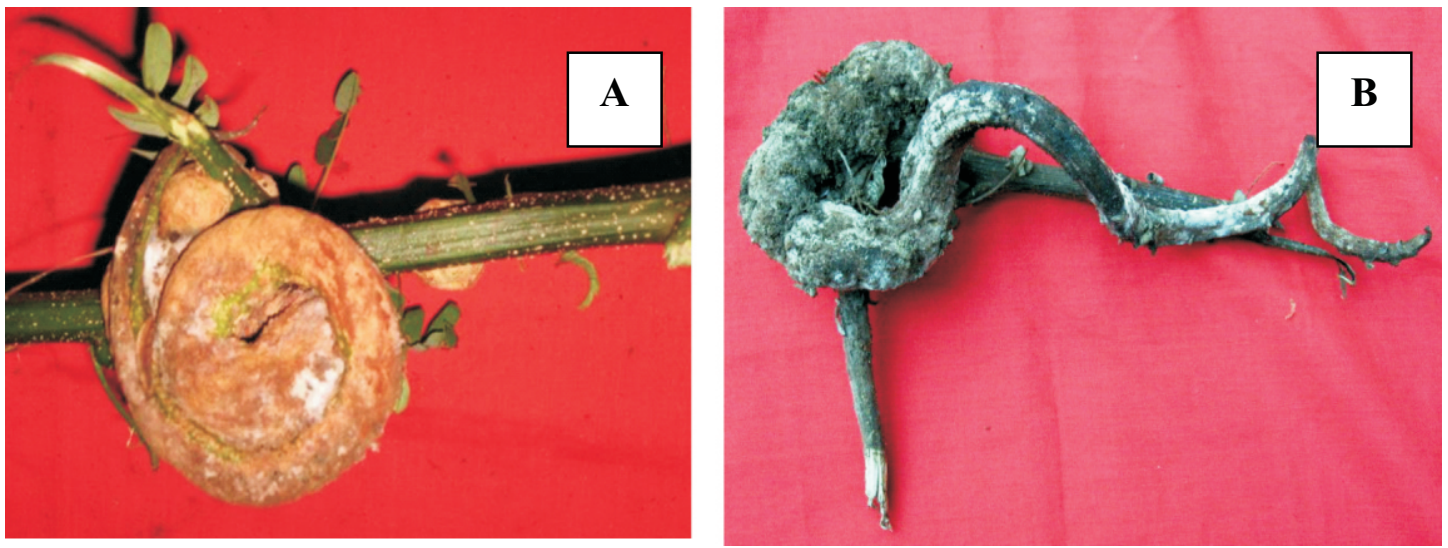

Gambar (Figure) 6. A. dan B. Bentuk tumor pada pucuk (Form of gall rust on shoot) 


\section{Persentase Kejadian Penyakit}

Persentase kejadian penyakit karat tumor pada sengon (tanpa perlakuan) di perkebunan PT. Glenmore dapat dilihat pada Tabel 1.

Tabel (Table) 1. Persentase kejadian penyakit karat tumor (Disease percentage of gall rust)

\begin{tabular}{|c|c|c|c|}
\hline \multirow{2}{*}{$\begin{array}{c}\text { No plot } \\
\text { (Plot number })\end{array}$} & \multicolumn{3}{|c|}{ Persentase kejadian penyakit (Disease percentage) (\%) } \\
\cline { 2 - 4 } & April & Juni & Agustus \\
\hline 1. & 99 & 99 & 99 \\
\hline 2. & 99 & 99 & 99 \\
\hline 3. & 98 & 98 & 98 \\
\hline 4. & 97 & 97 & 97 \\
\hline 5. & 97 & 97 & 97 \\
\hline Jumlah (Total) & 490 & 490 & 490 \\
\hline Rata-rata (Average) & 98 & 98 & 98 \\
\hline
\end{tabular}

Rata-rata persentase kejadian penyakit karat tumor pada pengamatan ke-1 (April) sebesar 98\%, pada pengamatan ke-2 (Juni) sebesar 98\% dan pengamatan ke-3 (Agustus) sebesar 98\% (Tabel 1).

\section{Intensitas Penyakit}

Persentase intensitas penyakit karat tumor pada sengon di perkebunan PT. Glenmore dapat dilihat pada Tabel 2 .

Tabel (Table) 2. Persentase intensitas penyakit karat tumor (Disease intensity of gall rust)

\begin{tabular}{|c|c|c|c|}
\hline \multirow{2}{*}{$\begin{array}{c}\text { No plot } \\
\text { (Plot number })\end{array}$} & \multicolumn{3}{|c|}{ Intensitas penyakit (Disease intensity) (\%) } \\
\cline { 2 - 4 } & April & Juni & Agustus \\
\hline 1. & 53,50 & 68,75 & 81,25 \\
\hline 2. & 67,75 & 72,50 & 75,25 \\
\hline 3. & 67,50 & 77,00 & 80,00 \\
\hline 4. & 76,75 & 81,50 & 81,75 \\
\hline 5. & 76,00 & 78,75 & 80,50 \\
\hline Jumlah (Total) & 341,50 & 378,50 & 398,75 \\
\hline Rata-rata (Average) & 68,30 & 75,70 & 79,75 \\
\hline
\end{tabular}

Rata-rata intensitas serangan penyakit pada pengamatan ke-1 (April) sebesar 68,30\%, kemudian meningkat pada pengamatan ke-2 (Juni) sebesar 75,70\% dan pengamatan ke-3 (Agustus) menjadi 79,75\% (Tabel 2). Peningkatan intensitas serangan karat tumor dari pengamatan ke-1 sampai ke-3 diduga ada hubungannya dengan lingkungan, karena lokasi perkebunan Glenmore terletak di tempat yang tinggi dari permukaan laut (400 - $550 \mathrm{~m} \mathrm{dpl),} \mathrm{curah} \mathrm{hujan} \mathrm{tinggi} \mathrm{sehingga} \mathrm{kelembabannya} \mathrm{tinggi} \mathrm{dan} \mathrm{makin} \mathrm{banyak}$ kabut. Hal ini merupakan kondisi ideal bagi pertumbuhan spora patogen karat tumor. 


\section{Uji Coba Pengendalian Penyakit Karat Puru}

- Hasil uji coba pengendalian di lapangan pada tanaman sengon yang terserang penyakit karat tumor menggunakan fungisida kimia sintetik dengan cara bor-infus ternyata tidak efektif. Hal ini ditunjukkan dengan makin meningkatnya persentase intensitas serangan pada setiap pengamatan.

- Uji coba pengendalian di lapangan pada tanaman sengon yang terserang penyakit karat tumor dengan menggunakan larutan spiritus, kapur campur garam dengan perbandingan $10: 1$ dan belerang campur kapur dengan perbandingan $1: 1$ setelah satu bulan perlakuan memberikan efek yang cukup baik, dimana pada bagian yang diberi perlakuan tidak tumbuh tumor kembali. Dari ketiga bahan tersebut di atas yang paling baik hasilnya adalah perlakuan belerang campur kapur dengan perbandingan $1: 1$.

\section{B. Pengamatan di Laboratorium}

Pengamatan pada preparat permanen menunjukkan piknium dalam keadaan tertutup maupun terbuka ke atas permukaan lapisan epidermis. Piknidium berbentuk bulat/mangkok atau berbentuk seperti botol dengan warna coklat kemerahan (Gambar 9). Fungi ini juga menghasilkan teliospora yang bentuknya bulat seperti payung. Oleh Old (2002) dikatakan bahwa teliospora fungi mempunyai rabungrabung (lipatan seperti payung) yang radial (Gambar 10).

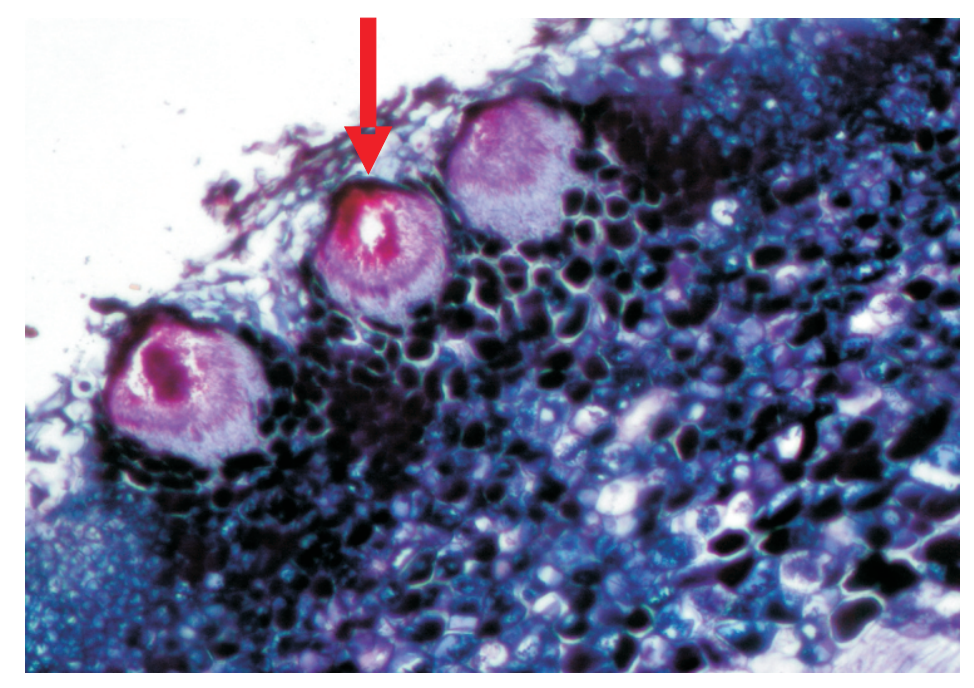

Gambar (Figure) 9. Piknium fungi karat tumor (Picnium of gall rust fungi)

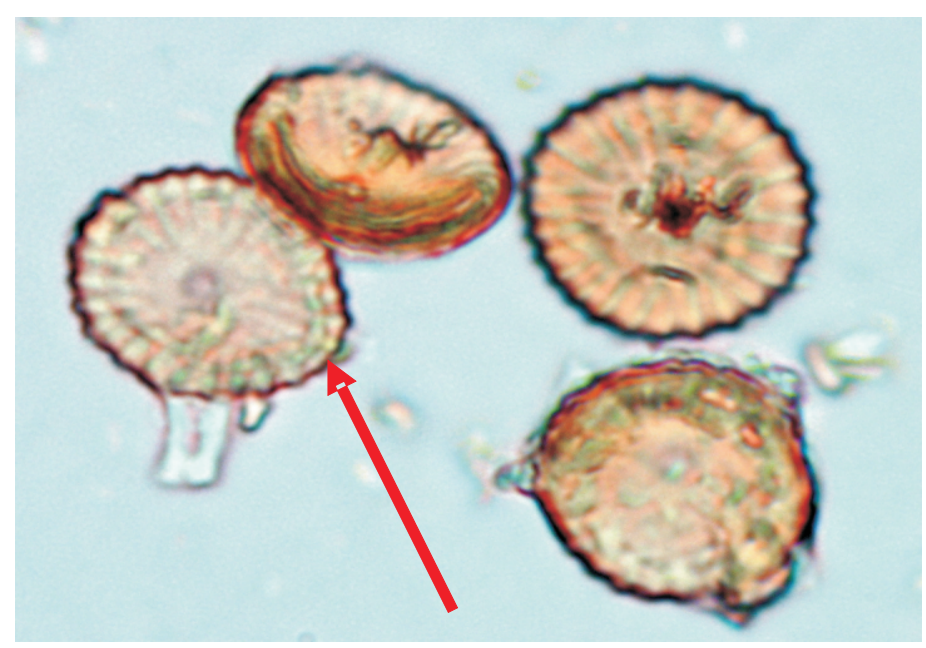

Gambar (Figure) 10. Bentuk teliospora fungi karat tumor (Teliospore of gall rust fungi) 
Berdasarkan pengamatan terhadap gejala penyakit di lapangan, Old dkk. (2000) dalam Old (2002) mengatakan bahwa hanya ada dua jenis Uromycladium yang diketahui mengakibatkan pembentukan bintil-bintil dalam jumlah sangat besar pada tunas berkayu dan bagian-bagian lain pohon akasia dan albisia yang terserang yaitu $U$. notabile dan $U$. tepperianum. Fungi ini dapat dibedakan dari morfologi teliospora yang dihasilkan secara seksual. Spora seksual (teliopsora) dengan rabung-rabung memencar ini merupakan ciri khas dari U. tepperianum, sedangkan uredospora aseksual dihasilkan oleh $U$. notabile. Dari uraian tersebut di atas maka diketahui bahwa penyebab penyakit karat tumor pada sengon di Jawa Timur adalah fungi U. tepperianum.

Franje et al. (1993) mengatakan bahwa penyakit karat tumor yang menyerang albisia di New Zealand disebabkan oleh Uromycladium yang mempunyai siklus hidup yang terdiri dari 3 tahap yaitu Piknial (0), Uredial (II), dan Telial (III). Teliospora tidak berkecambah tetapi infeksi dilakukan oleh uredospora. Semangun (1996) mengatakan bahwa bangsa Uredinales atau jamur karat umumnya dianggap parasit obligat dengan sifat-sifat : 1) miselium mengandung tetes-tetes minyak yang berwarna kuning atau jingga, tumbuh interseluler dan mengambil makanan dari sel-sel dengan houstorium; 2) sepanjang daur hidupnya jamur karat dapat membentuk lima macam spora (pikniospora, aesiospora, uredospora, teliospora dan basidiospora); 3) teliospora tumbuh menjadi promiselium; 4) pada jenis tertentu terdapat heterosisme (pembentukan bentuk-bentuk spora yang berbeda pada hospes yang berbeda).

Terbentuknya tumor merupakan gejala hiperplasia yang disebabkan oleh pembelahan sel yang bertambah banyak dan membentuk sel-sel yang lebih besar (hipertropi) yang akan menambah besar organ. Semangun (1996) mengatakan bahwa untuk timbulnya penyakit, patogen harus berhubungan dengan jaringan tumbuhan yang hidup dan berkembang di dalamnya. Aktivitas patogen dalam tumbuhan bersifat kimiawi, oleh karena itu pengaruh yang disebabkan oleh patogen pada tumbuhan hampir seluruhnya sebagai akibat reaksi-reaksi biokimia yang terjadi antara substansi yang dihasilkan oleh patogen dengan substansi yang terdapat dalam tumbuhan atau yang dibentuk tumbuhan saat terjadi infeksi. Kelompok-kelompok utama substansi yang disekresikan oleh patogen dalam tumbuhan yang menyebabkan timbulnya penyakit baik langsung maupun tidak langsung adalah enzim, toksin, zat pengatur tumbuh dan polisakarida. Timbulnya tumor erat kaitannya dengan hormon tumbuh yang terjadi secara alamiah dalam tumbuhan yaitu auksin, seperti indole-3-acetic acid (IAA) dan sitokinin. Tumbuhan yang sakit terutama pada sel-sel tumor mengandung kadar IAA dan sitokinin yang lebih tinggi daripada biasanya, kedua hormon tersebut diduga menimbulkan gejala hiperplasia, patogen yang masuk ke dalam tumbuhan berkembang biak di dalam ruang sela-sela sel, menyebabkan dipercepatnya pembelahan sel, dan sel yang terjadi membesar secara abnormal. Sinaga (2000) menyatakan bahwa dalam pertumbuhan normal tumbuhan terjadi satu seri kumpulan proses yang diatur dan dikoordinasi dengan baik sebagai proses metabolisme. Proses tersebut dikendalikan dengan hormon pengatur tumbuh, demikian juga oleh mekanisme kompensator. Patogen sangat mengganggu pertumbuhan inang dengan (a) memproduksi hormon yang menyebabkan respon abnormal dari inang, (b) memproduksi senyawa yang menstimulasi tumbuhan inang untuk memproduksi terlalu banyak/sedikit hormon tumbuh, (c) memproduksi zat pengatur tumbuh yang dalam keadaan normal telah diproduksi inang sehingga tingkat pengatur tumbuh menjadi lebih tinggi dibandingkan dengan tingkat dalam keadaan normal, dan (d) membentuk metabolit yang mempengaruhi sistem regulatori normal dari tumbuhan.

Pengukuran persentase kejadian penyakit (luas serangan penyakit) dan intensitas serangan penyakit karat tumor pada sengon dilakukan untuk mengukur perkembangan epidemik dan mengetahui faktor-faktor yang mempengaruhi perkembangan penyakit. Penyakit epidemik adalah meningkatnya penyakit dengan hebat pada waktu dan wilayah tertentu dalam satu populasi tumbuhan (Semangun, 1996). Sutakaria (1980) menyebutkan bahwa penyakit epidemik dipergunakan untuk penyakit yang merusak dengan persentase yang tinggi dalam suatu populasi tanaman. Jadi jumlah tanaman yang kena penyakit mencapai persentase yang tinggi oleh penyakit, dalam hubungan ini tidak dititikberatkan pada luas serangannya. Penyakit endemik juga menggambarkan suatu penyakit yang terbatas pada wilayah geografis tertentu atau penyakit yang selalu terdapat di daerah tertentu dengan menimbulkan kerugian ringan sampai berat. Beratnya penyakit yang infeksious ditentukan oleh berbagai variabel yaitu : 1) Ketahanan tanaman; 2) Jumlah patogen; 3) virulensi patogen; 4) kesesuaian keadaan lingkungan terhadap perkembangan patogen; 5) lamanya keadaan yang sesuai untuk patogen. Dengan demikian timbulnya ledakan (outbreak) penyakit secara luas tergantung dari : 1) Banyaknya tanaman rentan; 2) Banyaknya patogen yang virulen; 3 ) Keadaan lingkungan yang sesuai untuk patogen dalam jangka waktu lama. 
Intensitas serangan penyakit karat tumor sengon di lapangan menunjukkan tendensi yang berubah dari waktu ke waktu yang berbeda, dengan demikian fluktuasi penyakit karat tumor tidak ditentukan oleh faktor genetik ataupun oleh perubahan zat hara tanah, tetapi lebih dipengaruhi oleh beberapa faktor iklim makro. Parameter cuaca yang minimal sangat berperan dan dapat dipakai sebagai penduga intensitas penyakit karat tumor seperti suhu udara, intensitas penyinaran matahari dan curah hujan rata-rata per hari/per bulan.

\section{KESIMPULAN}

1. Penyakit karat tumor pada sengon di perkebunan PT. Glenmore Banyuwangi disebabkan oleh fungi Uromycladium tepperianum.

2. Persentase kejadian penyakit di lokasi penelitian yaitu di perkebunan PT. Glenmore mencapai 98\% dan intensitas serangan penyakit mencapai $79,75 \%$. Dengan demikian penyakit karat tumor pada sengon sudah menjadi penyakit epidemi, yaitu penyakit yang merusak dengan persentase yang tinggi dalam suatu populasi tanaman. Jadi jumlah tanaman yang kena penyakit mencapai persentase yang tinggi oleh penyakit, dalam hubungan ini tidak dititikberatkan pada luas serangannya.

3. Pengendalian pendahuluan menggunakan beberapa jenis fungisida sintetik tidak dapat mencegah dan mengendalikan penyakit. Sedangkan pengendalian dengan campuran antara belerang dan kapur dengan perbandingan $1: 1$ dapat mencegah timbulnya kembali tumor.

\section{DAFTAR PUSTAKA}

Alrasjid, H. 1972. Beberapa keterangan tentang Albizia falcataria (L) Fosberg. Menara Perkebunan 40 (4): 153158.

Alexopoulos, C.J. and C.W. Mims. 1979. Introductory Mycology. John Wiley \& Sons.

Anggraeni, I. dan E. Santoso. 2003. Penyakit karat puru pada sengon (Paraserianthes falcataria) di Pulau Seram. Buletin Penenlitian Hutan. No. 636/2003. Puslitbang Hutan dan Konservasi Alam Bogor.

Anonimous. 1990. Peta kesesuaian agroklimat pengembangan hutan tanaman industri (Albizia falcataria) di Pulau Jawa. Kerjasama Metereologi Pertanian Indonesia dengan Badan Litbang Kehutanan. Departemen Kehutanan. Jakarta.

Franje, N.S, H. C. Alovera, I. M. Olazo, E. E. Danlag, L. N. Capili, R. B. Alovera, CMU. Gall Rust of Falcata (Albizzia falcataria L.) Back: Its Biology and Identification. Http:// www.pcarrd.dost.gov.ph/consortia/nomcarrd/researches/1993/1993 r5.htm.Diakses pada 2710-2008.

Old, K.M., L.S. See, J.K. Sharma, and Z.Q. Yuan. 2000. A Manual of Diseases of Tropical Acacias in Australia, South-East Asia and India. Center for International Forestry Research (CIFOR). Jakarta.

Old, K.M. 2002. Misi penelitian madre cacao. Laporan untuk klien, No. 1119 Juni 2002. Klien : Dinas Pembangunan Internasional Australia (Australian Agency for International Development). Produk Hutan dan Kehutanan CSIRO. Canberra.

Schmidt, F.H. and J.H.A. Ferguson. 1951. Rainfall Types Based on Wet and Dry Period Ratios for Indonesia with Western New Guinea. Verh. No. 42. Direktorat Meteorologi dan Geofisika. Jakarta.

Semangun, H. 1996. Pengantar Penyakit Tumbuhan. Gadjah Mada University Press. Yogyakarta.

Sinaga, M. 2000. Diktat Kuliah. Dasar-dasar Penyakit Tumbuhan. Fakultas Pertanian Jurusan Hama dan Penyakit. Institut Petanian Bogor. Bogor.

Sutakaria, J. 1980. Diktat Ilmu Penyakit Tumbuhan. Fakultas Pertanian, Departemen Ilmu Hama dan 